\title{
Morpho-physiological response to drought of progenies of Pinus taeda L. contrasting in mean growth rate
}

\author{
Nardia Maria Lujan Bulfe ${ }^{1} \cdot$ Maria Elena Fernández $^{2}$
}

Received: 17 June 2015/ Accepted: 9 January 2016

(C) Springer Science+Business Media Dordrecht 2016

\begin{abstract}
Potential trade-offs between growth and water stress resistance in Pinus taeda L. families, and the ecophysiological processes involved were evaluated. Families of high (HG) and low (LG) growth rate were subject to moderate and severe water stress. Families only differed in growth under the high water availability condition (control treatment), declining exponentially to similar values in all families under drought. HG families presented higher absolute growth but lower relative growth than LG families. Hydraulic conductivity of branches decreased at high air saturation deficit $(D)$ even with high soil water content due to high vulnerability to cavitation (mean $P_{50}=1.7 \mathrm{MPa}$ ) and poor stomatal control of water potential in all families (which was even lower in LG). LG families presented higher carbon fixation capacity (per unit leaf area) but this could not be reflected in absolute growth due to their higher biomass allocation to roots compared to $\mathrm{HG}$ families. HG2 family allocated more biomass to leaves than the other families, increasing its whole capacity of C fixation. HG1 family had a differential allocation to the stem, probably increasing whole hydraulic conductance and capacitance, and therefore having an efficient way of providing water to the leaves. Our results does not support the hypothesis of a tradeoff between growth and drought resistance in Pinus taeda, but that there are different combinations of traits, as those of HG families, leading to high absolute growth when soil water availability is high, and low growth— but similar to that of LG familiesunder water deficit conditions.
\end{abstract}

Keywords Genetic variability $\cdot$ Growth $\cdot$ Allometry $\cdot$ Loblolly pine $\cdot$ Resource use efficiency

Nardia Maria Lujan Bulfe

bulfe.nardia@inta.gob.ar

1 MsC Instituto Nacional de Tecnología Agropecuaria (EEA Montecarlo), Av. El Libertador 2472, 3384 Montecarlo, Misiones, Argentina

2 Dra. CONICET (INTA EEA Balcarce-Oficina Tandil), General Rodríguez 370, 7000 Tandil, Buenos Aires, Argentina 


\section{Introduction}

The frequency and intensity of some storm and drought events as well as the amount and temporal distribution of precipitation have changed over the past 50 years in several regions of the world (IPCC 2007). As for other subtropical regions of the world, it is postulated that the subtropical area in North-Eastern Argentina, South America, which constitutes the country's main region providing forestry products, could undergo a severe increase in water deficit in spring and summer months (Hulme and Sheard 1999). This background, added to the expansion of forest plantations into more marginal sites (Faustino et al. 2011; Martiarena et al. 2014) due to competition with other land uses suggest that resilience and productivity of tree crops will be compromised in the future.

Pinus taeda L. (loblolly pine) is an important tree species in its country of origin, USA (Baker and Langdon 2012; report USFS), and the main exotic species introduced in Argentina (MAGyP 2013). Genetic improvement implemented for decades has allowed a substantial increase in the productivity of this species, both in North America (Tree Improvement Cooperative Program (CTIP-NC State University), Cooperative Research Forest Biology (FBRC-University of Florida) and Arkansas Forestry Commission (AFC), among others), and in Argentina, where the genotypes best adapted to local conditions are used. Breeding programs in Argentina have achieved significant increases in productivity, but without knowledge of the physiological basis for the higher growth rates of selected loblolly pines or their adaptability to different stress conditions. Taking into account predicted future climate change, it is essential to understand the potential trade-offs between productivity and stress resistance, in which the hydraulic characteristics of the species and other morpho-physiological mechanisms play a key role. In this regard, it is predicted for NE region of Argentina, the main forestry area of this country, that in addition to higher mean temperature, precipitation level will increase but with higher variability between years than the present conditions resulting in frequent dry seasons (Hulme and Sheard 1999).

Among the plant hydraulic components, the specific hydraulic conductivity $\left(k_{\mathrm{s}}\right)$ of various organs, such as branches, is known to be directly related to the growth of individual plants in both hardwoods (Brodribb et al. 2005; Kondoh et al. 2006) and coniferous trees (Domec and Gartner 2003; Wang et al. 2003). This is affected by xylem cavitation (Hacke and Sperry 2001), which occurs when tension thresholds are exceeded due to water deficit in the soil and/or the atmosphere, resulting in growth loss and in the worst cases, the death of the plant (Sperry and Pockman 1993; Rice et al. 2004; Bréda et al. 2011).

In general, it is argued that there is a trade-off between the hydraulic efficiency and the safety of the conductive system (Kondoh et al. 2006; Domec et al. 2006), which has been revisited by Sperry et al. (2008). However, in some species or some genotypes within them there exist combinations of traits that allow hydraulic conductivity and safety to be maximized at the same time (Wang et al. 2003; Burgess et al. 2006). On the other hand, in some species, such as ponderosa pine, resistance to water stress has no direct relationship with vulnerability to cavitation (Zhang et al. 1997; Domec and Gartner 2003). High growth rates in trees of this species are possible under stress conditions through a strategy highly wasteful of water when it is available, and highly conservative, when it is in deficit.

The aim of this study was to evaluate the trade-offs between growth and water stress resistance at early ages of $P$. taeda genotypes with different growth rates and the morphophysiological processes responsible for the patterns observed. It was hypothesized that there is a trade-off between growth and water stress resistance because the plant structures 
that allow high growth (e.g. great development of leaf area and high $k_{\mathrm{s}}$ ) are penalizing in the presence of water stress due to increased transpiration surface and increased vulnerability to cavitation, respectively.

\section{Materials and methods}

\section{Study site and experimental design}

The experiment was conducted in a greenhouse located in Montecarlo, Misiones Province, Argentina $\left(26^{\circ} 30^{\prime} \mathrm{S}, 54^{\circ} 40^{\prime} \mathrm{W}\right)$. The annual average monthly temperature in the greenhouse was $23.4 \pm 1.6{ }^{\circ} \mathrm{C}$ and the relative humidity was $71.5 \pm 5.5 \%$. In April 2010, four Pinus taeda L. parent trees were selected from a 15-year-old clonal seed orchard belonging to the breeding program of the National Institute of Agricultural Technology (INTA) of Argentina. All families used in this study belong to "local provenances" of Misiones province (Montecarlo, Iguazú, Eldorado), which in fact correspond to Marion County (Florida, USA) origin, the most widespread provenance used in this Breeding Program. There are also genotypes from other origins (such as Columbia and Futululu), but they are much less represented in the Program than Marion provenance. Two of the four selected half-sib families for this study have high volume growth rates (HG1 and HG2) and the other two half-sib families have relatively low growth rates (LG1 and LG2). This selection was based on a ranking of the first generation of parent plants at five years old.

Seeds of the four families were subjected to pre-germinative treatment (humid conditions at $4{ }^{\circ} \mathrm{C}$ ) during 60 days. In December 2010, they were sown in commercial seedling starter trays. In April 2011, 36 seedlings from each family were transplanted to 20-1 pots, containing as substrate $1 / 3$ red soil (ultisol, in which the species is normally cultivated in Misiones), $1 / 3$ pine bark and $1 / 3$ sand. This substrate mixture was chosen in order to facilitate roots recovery after the experiment, since root biomass production was one of the studied variables (see below). When plants were transplanted into the 201 pots, they had a height of about $40 \mathrm{~cm}$. The exact size of each plant was recorded at the beginning of treatments implementation (see Table 1), 5 months after transplanting (plants were 7 months-old at this moment). The plants were divided into three treatments: Control (C) plants were irrigated to soil saturation (approximately $2000 \mathrm{~cm}^{3} /$ plant) twice a week; moderate stress (SA): plants were irrigated with the same frequency as $\mathrm{C}$ but with less water $\left(500 \mathrm{~cm}^{3} /\right.$ plant on each irrigation date); severe stress $(\mathrm{SB})$ : the frequency of irrigation was decreased to once a week, with the same amount of water as in SA. All treatments were applied from September 12, 2011, to January 11, 2012, comprising the main growth period of the species in the study region. No additional fertilization was added to the pots than the nutrients present in the substrate (particularly, red soils), which is considered as having enough quantities to allow proper plants growth. Moreover, there are studies (Faustino et al. 2013) indicating that $\mathrm{N}$ addition in this type of soils produces growth decrease in Pinus taeda, with an opposite response with $\mathrm{P}$ addition, so we avoided the complex interaction effects of nutrients addition in this study in order to analyze responses to drought.

Irrigation treatments were determined considering that plants in the control situation receive enough water not to decrease their pre-dawn water potential below $-0.5 \mathrm{MPa}$. From preliminary measurements relating pre-dawn water potential and soil water content, 
Table 1 Mean \pm SD of size variables recorded in each treatment at the beginning and at the end of the experimental period

\begin{tabular}{lllllll}
\hline Treatment & Progeny & $\mathrm{H}_{\mathrm{ti}}$ & $\mathrm{dac}_{\mathrm{i}}$ & $\mathrm{H}_{\mathrm{tf}}$ & $\mathrm{Dac}_{\mathrm{f}}$ & $\mathrm{B}_{\mathrm{tf}}$ \\
\hline Control & $\mathrm{HG} 1$ & $74.6 \pm 11.7$ & $8.0 \pm 1.3$ & $128.0 \pm 20.4$ & $12.6 \pm 1.9$ & $118.5 \pm 22.1$ \\
& $\mathrm{HG} 2$ & $68.8 \pm 12.4$ & $7.4 \pm 1.4$ & $122.5 \pm 18.3$ & $12.3 \pm 2.0$ & $103.6 \pm 35.1$ \\
& $\mathrm{LG} 1$ & $53.5 \pm 6.1$ & $6.3 \pm 0.9$ & $115.5 \pm 11.8$ & $11.2 \pm 0.9$ & $81.9 \pm 10.5$ \\
& LG2 & $49.0 \pm 6.1$ & $6.3 \pm 1.0$ & $110.4 \pm 10.0$ & $10.7 \pm 1.2$ & $83.3 \pm 15.0$ \\
SA & HG1 & $75.4 \pm 21.0$ & $7.2 \pm 1.6$ & $96.3 \pm 21.8$ & $8.9 \pm 1.5$ & $51.1 \pm 17.6$ \\
& HG2 & $65.9 \pm 19.1$ & $7.2 \pm 1.7$ & $91.1 \pm 16.7$ & $9.3 \pm 1.3$ & $63.5 \pm 8.2$ \\
& LG1 & $49.8 \pm 10.8$ & $5.6 \pm 1.4$ & $77.8 \pm 12.1$ & $8.1 \pm 1.0$ & $45.3 \pm 14.8$ \\
& LG2 & $52.8 \pm 7.1$ & $7.0 \pm 1.6$ & $83.4 \pm 6.3$ & $8.8 \pm 1.2$ & $53.9 \pm 8.6$ \\
& HG1 & $68.8 \pm 10.9$ & $7.2 \pm 1.3$ & $84.8 \pm 12.2$ & $8.1 \pm 0.9$ & $30.7 \pm 5.3$ \\
& HG2 & $60.5 \pm 13.4$ & $7.0 \pm 1.9$ & $80.2 \pm 10.4$ & $8.2 \pm 1.3$ & $38.6 \pm 10.4$ \\
& LG1 & $54.3 \pm 11.9$ & $6.3 \pm 1.1$ & $74.1 \pm 16.9$ & $7.5 \pm 1.2$ & $29.2 \pm 10.5$ \\
& LG2 & $47.3 \pm 11.5$ & $5.9 \pm 0.8$ & $63.2 \pm 16.1$ & $7.4 \pm 1.4$ & $23.8 \pm 6.7$ \\
\hline
\end{tabular}

$S A$ moderate water stress, $S B$ severe water stress, $H G$ high growth families, $L G$ low growth families, $H_{t i}$ initial plant height in $\mathrm{m}, d a c_{i}$ initial basal diameter in $\mathrm{mm}, H_{t f}$ final (end of experiment) plant height in $\mathrm{m}$, $d a c_{f}$ final basal diameter in $\mathrm{mm}, B_{t f}$ final plant biomass in $\mathrm{g}$

this water potential level is reached with soil water around 18 vol\%. The amount of water needed to reach that value in 201 pots with soil with water retention capacity of that used in the experiment was 3.61 considering that the soil is completely dry. In addition, in preliminary measurements it was determined that plants of the same families and similar sizes that those used here transpire in average 0.41 of water per day. Therefore, we began the experiment providing water in excess to field capacity, and then we added water to replace (or even surplus) the water used in the days between two irrigation dates in the case of the control situation. In the water stressed treatments, the amount of water added was lower than water used by transpiration leading to moderate and severe water deficit.

\section{Variables measured}

Plant total height $\left(H_{\mathrm{t}}, \mathrm{m}\right)$ and stem basal diameter $(\mathrm{RCD}, \mathrm{mm})$ were recorded approximately every 15 days on a mark made on the stem at $10 \mathrm{~cm}$ from the substrate surface $(\mathrm{n}=12)$. The volume of each individual stem was estimated considering it had a cylindrical shape. Since many eco-physiological variables were measured during the study and in order to focus on the main results, in this paper only initial and final values of stem volume are used to estimate its absolute and relative increment.

At the end of the experiment, six plants from each family and treatment were harvested to estimate above- and belowground biomass production and its partitioning to foliage, branches, stem and roots. All plant organs were dried to a constant mass at $60{ }^{\circ} \mathrm{C}$ and weighed.

The increment in stem volume throughout the experiment was estimated in absolute and relative values according to the following equations:

Absolute Increment

$$
A I=G_{2}-G_{1}
$$


Relative Increment

$$
R I=\frac{G_{2}-G_{1}}{G_{1}} \times 100
$$

where $G_{1}$ : Stem volume at the beginning of the experiment $\left(\mathrm{cm}^{3}\right), G_{2}$ : Stem volume at the end of the experiment $\left(\mathrm{cm}^{3}\right)$.

Leaf water potential $\left(\Psi_{\text {leaf }}, \mathrm{MPa}\right)$ was recorded monthly in one needle of two plants per treatment and family, at pre-dawn (5 a.m.), mid-morning (9 a.m.), and in the afternoon (2 p.m.) with a pressure chamber (BIO-CONTROL, Argentina, model $6 \mathrm{MPa}$ ). Stomatal conductance $\left(g_{\mathrm{s}}\right.$, mol m $\left.\mathrm{m}^{-2} \mathrm{~s}^{-1}\right)$ was measured immediately after $\Psi_{\text {leaf }}$ determinations with a porometer (Decagon Devices SC-1).

Maximum photosynthetic rate $\left(A_{\max }, \mu \mathrm{mol} \mathrm{m} \mathrm{m}^{-2} \mathrm{~s}^{-1}\right)$, at light saturation $\left(1200 \mu \mathrm{mol} \mathrm{m} \mathrm{m}^{-2} \mathrm{~s}^{-1}\right.$ ), was measured in October 26 and 27, 2011 (end of a dry down period in each treatment, i.e. just before the corresponding next watering), on fully expanded fascicles $(\mathrm{n}=4)$ with an infrared gas analyzer (PPSystems TPS-2; $\mathrm{CO}_{2}$ concentration: $400 \mathrm{ppm}$; mean air temperature during measurements: $25^{\circ} \mathrm{C}$ ). This measurement was carried out during a period of maximum growth rate, as determined in a complementary experiment.

In order to determine the short-term response of $g_{s}$ to vapor pressure deficit of the atmosphere $(D, \mathrm{kPa}), g_{\mathrm{s}}$ was measured every $30 \mathrm{~min}$ between 10 a.m. and 2 p.m. on December 13 and 14, 2011. The $D$ was estimated from relative humidity and temperature data automatically registered with a thermo-hygrometer Hobo (Pro v2 Onset) placed in the greenhouse. Sensitivity of $g_{\mathrm{s}}$ to $D$ was analyzed as in Oren et al. (1999), relating $g_{\mathrm{s}}$ and $\ln$ $D$, and estimating the slope (sensitivity) and intercept (reference $g_{\mathrm{s}}$, that is $g_{\mathrm{s}}$ at $D=1 \mathrm{kPa}$ ) of that linear relationship.

On the same dates as $g_{\mathrm{s}}$ response to $D$ determinations $(\mathrm{n}=4)$, in situ specific hydraulic conductivity $\left(k_{\mathrm{s}}, \mathrm{kg} \mathrm{s}^{-1} \mathrm{~m}^{-2} \mathrm{MPa}^{-1}, \mathrm{n}=4\right)$ was determined in branches, expecting minimum daily values since branches were sampled at hours with the highest evaporative demand (2 p.m.). $k_{\mathrm{s}}$ was measured using a multi-channel conductivity meter made of PVC, with eight channels. It consists of a water container placed $1 \mathrm{~m}$ high to generate a pressure gradient, and silicone couplers to join the branches (e.g. Fernández et al. 2010). Water perfused in each branch was collected in a container, and then weighed on a digital scale with a precision of $0.001 \mathrm{~g}$. For the purpose of strengthening $k_{s}$ data detailed above, maximum $k_{\mathrm{s}}$ (branches sampled early in the morning and soaked to rehydration) and leaf specific hydraulic conductivity $\left(k_{1}, \mathrm{~m} \mathrm{~s}^{-1} \mathrm{MPa}^{-1}\right)$, i.e. hydraulic conductivity $\left(k_{h}\right.$, $\mathrm{kg} \mathrm{m} \mathrm{s}^{-1} \mathrm{MPa}^{-1}$ ) divided by foliar biomass fed by the measured branch section, were measured in four additional plants from the same families growing under control conditions and at one level of water stress in an additional trial.

Vulnerability to cavitation curves, that is the relationship between loss of $k_{s}$ and xylem tension, were determined by the air-injection method in approx. $10 \mathrm{~cm}$ long segments of branches of seedlings growing in the control situation $(n=4)$. The slope of the relationship and the $P_{50}$ (water potential at which $50 \%$ of $k_{s}$ is lost) were estimated adjusting the model (Pammenter and Vander Willigen 1998):

$$
P L C=\frac{100}{1+\exp \left(a\left(\Psi-P_{50}\right)\right)}
$$

Then, $P_{12}$ (air entry point) and $P_{88}$ were estimated as: 


$$
\begin{gathered}
P_{12}=\frac{2}{a}+P_{50} \\
P_{88}=\frac{-2}{a}+P_{50}
\end{gathered}
$$

The following variables were also determined at the end of the experiment:

- Leaf chlorophyll concentration $(n=9)$ : was determined with a spectrophotometer (SHIMADZU UV-160 A). Portions of needles $(2 \mathrm{~cm}$ long) were placed in dimethylformamide, which remained in the dark for at least $48 \mathrm{~h}$ prior to analysis. The chlorophyll concentration (total, chlorophyll a and b) was determined as in Inskeep and Bloom (1985).

$$
\begin{aligned}
& \operatorname{chl}_{t}(\mathrm{mg} / \mathrm{g})=17.9 \times A_{647}+8.08 \times A_{664.5} \\
& \operatorname{chl}_{a}(\mathrm{mg} / \mathrm{g})=12.7 \times A_{664.5}-2.79 \times A_{647} \\
& \operatorname{chl}_{b}(\mathrm{mg} / \mathrm{g})=20.7 \times A_{647}-4.62 \times A_{664.5}
\end{aligned}
$$

where $A_{664.5}$ is absorbance at $664.5 \mathrm{~nm}$, maximum absorbance for chlorophyll a, and $A_{647}$ is absorbance at $647 \mathrm{~nm}$, maximum absorbance for chlorophyll b.

- Leaf nitrogen content $(n=4)$ : was determined using the total nitrogen method following Kjeldah (IRAM 29572-1).

- Growth efficiency $\left(\mathrm{cm}^{3} \mathrm{~g}^{-1}\right)$, GE: was estimated as the ratio of the absolute stem volume increment in the experiment period and total leaf biomass of each plant. This variable was measured in 6 plants per family and treatment, taking into account the dry weight (oven-dried at $60{ }^{\circ} \mathrm{C}$ until constant weight) of the whole leaf biomass of each plant.

- Nitrogen productivity: $\left(\mathrm{cm}^{3} \mathrm{~g}^{-1}\right)$, NP: was estimated as the ratio between the absolute stem volume increment in the experiment period and leaf nitrogen content in the total leaf biomass of each plant. This variable was estimated in 5 plants per family and treatment, considering the total $\mathrm{N}$ content present in the whole plant leaf biomass (estimated from its dry weight, as indicated above). Leaves are the organs that concentrate most of the $\mathrm{N}$ in the plant; therefore we used only leaf $\mathrm{N}$ content in NP estimation, resulting in some overestimation of the actual NP which must also consider $\mathrm{N}$ content in other plant organs. Moreover, NP was used as a proxy for plant $\mathrm{N}$ use efficiency assuming that the mean $\mathrm{N}$ residence time was similar in all situations.

- Intrinsic water-use efficiency, $\mathrm{WUE}_{\mathrm{i}}$ : the ratio of the ${ }^{13} \mathrm{C}$ to ${ }^{12} \mathrm{C}$ in woody tissue (stem + branches, $\delta^{13} \mathrm{C}, \%$ ) was used as a proxy for WUEi. The samples $(n=4)$ were analyzed in an isotope ratio mass spectrometer (Finnigan MAT Delta S, USA) following the methodology of Hoefs and Schidlowski (1967) and Panarello (1987) in the Institute of Geochronology and Isotopic Geology (Instituto de Geocronología y Geología Isotópica, INGEIS, CONICET-University of Buenos Aires, Argentina).

\section{Statistical analysis}

A factorial analysis of variance (ANOVA, $\alpha=0.05$ ) was applied to evaluate the effects of the following sources of variation: growth rate (GR, with levels HG and LG), water stress $($ WS, with levels $\mathrm{C}, \mathrm{SA}$ and SB), GR $\times$ WS interaction, and family nested within GR. 
Post-hoc Tukey tests were applied when interaction or any main factor effect was significant $(\alpha=0.05)$. ANOVA analyses were performed with $R$ statistical software (Team RC 2014).

In addition, some variables were analyzed by regression analysis, relating response variables to the gradient of water stress to which the plants were subject, quantified as the integral of water potential (MPa day) for each family and treatment. In this regard, although in each treatment all plants were subject to the same irrigation level, this variable can incorporate variation in water availability that might occur among individual plants due to differences in plant size and/or water use rates. Based on Myers (1988), for each family and treatment the water stress integral was calculated as:

$$
\int \psi=\sum\left|\psi_{i}\right| \times n
$$

where $\int \psi=$ water stress integral; $\left|\psi_{i}\right|=$ is the average predawn water potential (absolute value) of each family for the time period $\mathrm{i}, \mathrm{n}=$ number of days in the period $i$ (time between two successive measurements).

The simplest equation describing the relationship between volume increment and water stress integral was $\ln y=a+(b / x)$. Non-linear regression analyses were performed with the software Table Curve 2D (Jandel Scientific, AISN Software).

Differences between treatments and families in dry weight allocation to leaf, stem and root fractions were evaluated as in Bongarten and Teskey (1987) with linear regressions relating each compartment biomass and total plant biomass. Then, whole treatments models were compared with $F$ tests (Zar 1999):

$$
F_{o b s}=\frac{(\operatorname{SSE}(R)-\operatorname{SSE}(F)) / 2}{\left(\operatorname{SSE}(F) /\left(n_{1}+n_{2}-4\right)\right)}
$$

where $\operatorname{SSE}(\mathrm{R})=$ error sum of squares of pooled data model (treatments 1 and 2); $\operatorname{SSE}(\mathrm{F})=$ sum of squares of the model of treatment $1+$ sum of squares of the model of treatment $2 ; n_{1}$ and $n_{2}=$ number of replicates in each treatment.

Differences in parameters (slope and intercept) of the linear models between treatments were analyzed with Dummy auxiliary variables with InfoStat software.

\section{Results}

\section{Characterization of treatments}

Both plant height $\left(H_{\mathrm{i}}, \mathrm{cm}\right)$ and stem basal diameter (RCD, mm) differed significantly between HG and LG plants (18.2 cm of mean difference in height, and $1.1 \mathrm{~mm}$ in RCD) at the beginning of the experiment ( $p<0.0001$ both height and basal diameter) (Table 1). In addition, HG1 plants were in average $8.7 \mathrm{~cm}$ taller than HG2 $(p<0.05)$ (Table 1).

Considering the whole experiment period, mean $\int \Psi$ values were similar among families, averaging 52.3, 103.1 and 174.2 MPa days in control, SA and SB, respectively. Mean pre-dawn water potential for each treatment during the whole studied period was $-0.46 \pm 0.19,-0.89 \pm 0.55$ and $-1.41 \pm 0.90 \mathrm{MPa}$ for $\mathrm{C}, \mathrm{SA}$ and SB respectively. 


\section{Stem growth and biomass partitioning}

Both GR and WS had a significant effect on the absolute ( $p=0.0045$ and $p<0.0001$ respectively) and on the relative stem volume increment ( $p<0.0001$ in both GR and WS) throughout the study period, with a significant interaction between factors $(p=0.0037$ for absolute and $p=0.0005$ for relative stem volume increment) and no differences between families of each GR group. Regarding absolute growth, HG plants had higher volume increment than LG plants, and in both cases, control plants had greater growth than both WS treatments, with no differences between them (Fig. 1a). In average, the decrease in absolute growth for plants under SA treatment was $72 \%$ of that for control plants, while for plants under the most severe treatment (SB), growth decreased $85 \%$ compared to control plants. Considering relative stem volume increment, LG plants presented higher relative growth than $\mathrm{HG}$ plants (Fig. 1b). The magnitude of the decline in relative volume increment due to the effect of water stress was lower than in the case of absolute values (a decrease of $63 \%$ in SA and $80 \%$ in the SB, both compared to the control). Adjusted models to the relationship between growth and water status (see Fig. 1 for models) presented $\mathrm{R}^{2}$ values higher than 0.9 in all cases, differing between $\mathrm{HG}$ and LG families ( $\mathrm{F}$ test, $p<0.05)$.

Total plant biomass (aboveground + belowground) at the end of the study was affected by both GR $(p=0.0002)$ and WS $(p<0.0001)$, the biomass being reduced with increasing stress intensity, and the HG families having higher biomass than LG $(p<0.05)$. Aboveground biomass at the end of the experiment was also affected by both GR $(p<0.0001)$ and WS $(p<0.0001)$, in the same direction as total biomass, whereas belowground biomass (roots) was only affected by WS (averages \pm SD for all families: $23.7 \pm 7.6 \mathrm{~g}, 11.9 \pm 3.2 \mathrm{~g}$ and $8.0 \pm 2.2 \mathrm{~g}$ for control, SA and $\mathrm{SB}$, respectively; $p<0.0001)$.

In the allometric relationships analyzed, effects of WS treatment were observed in all cases (Fig. 2). Considering the different components within the aboveground fraction, the

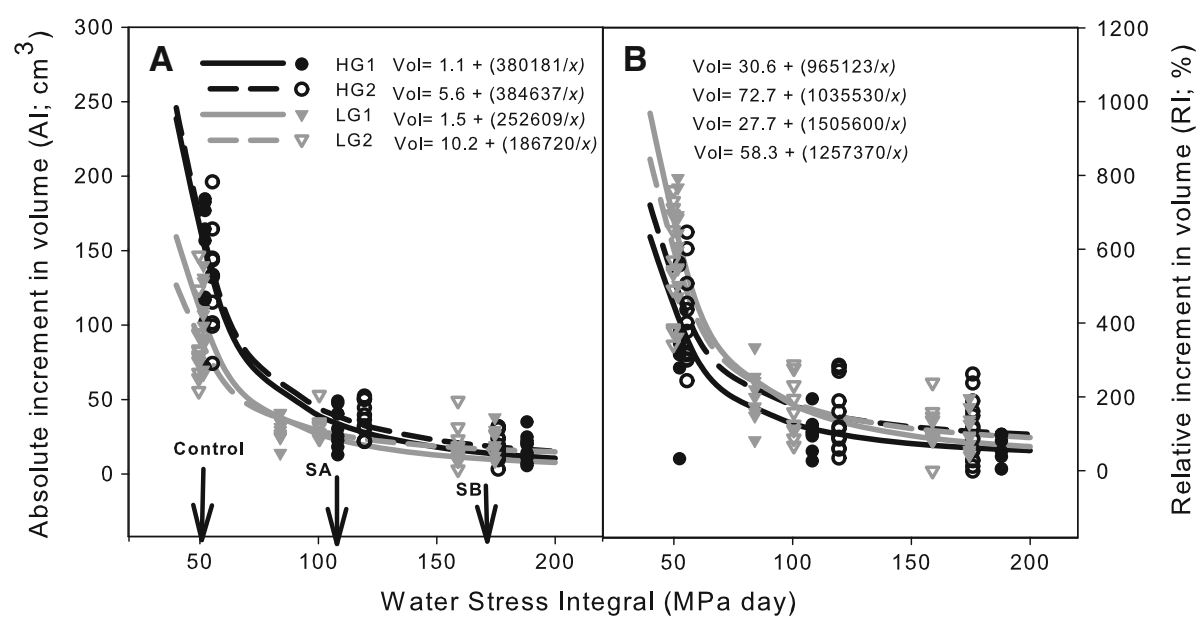

Fig. 1 Stem volume increment $\left(\mathrm{cm}^{3}\right)$ during the experiment period (September 2011-January 2012) in high growth (HG) and low growth (LG) families of loblolly pine growing under different conditions of water availability, as a function of the water stress integral (MPa day). a Absolute stem volume increment. b Relative stem volume increment. Lines represent the fitted models $\left(R^{2}>0.90\right.$ in all cases) 

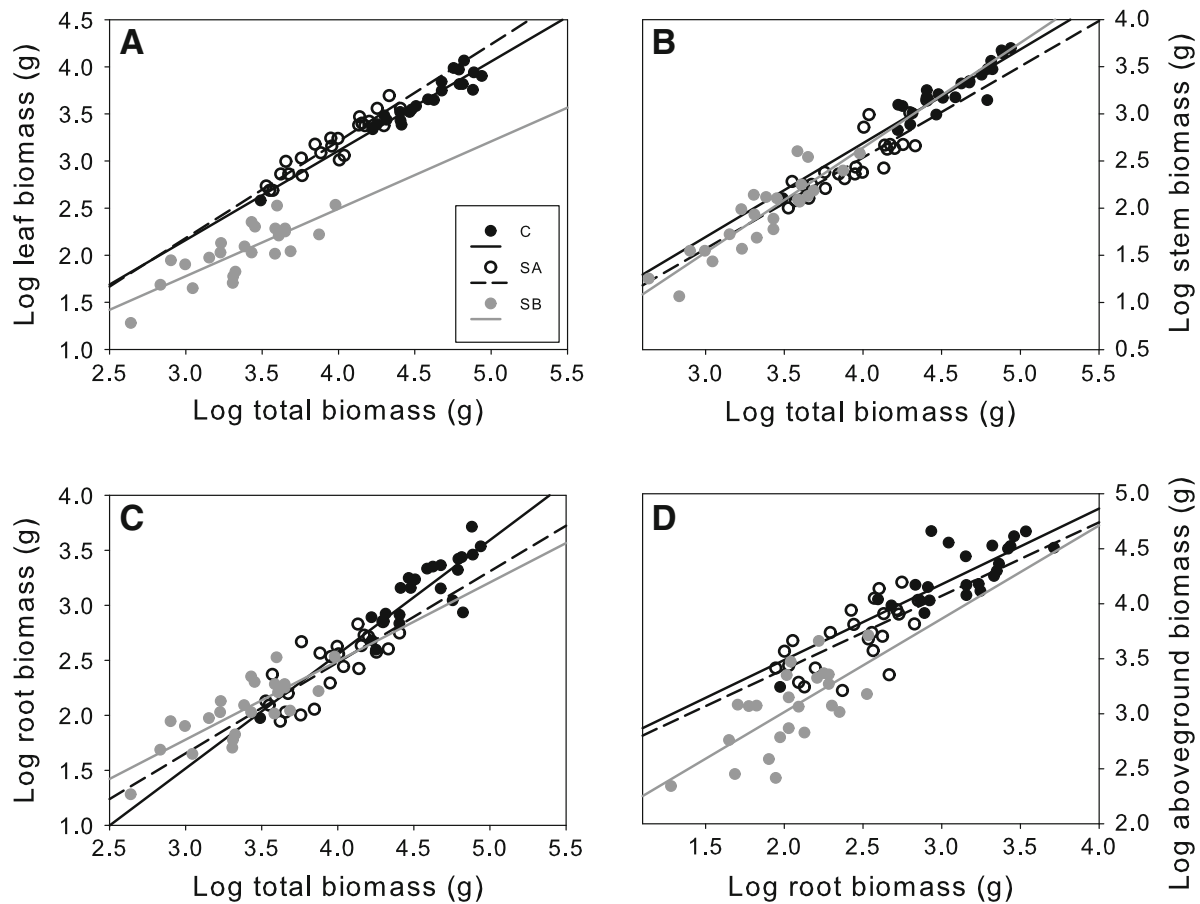

Fig. 2 Allometric relationships for seedlings (pool data of four families) of Pinus taeda L. growing at different soil water conditions. a Relationship between leaf and total plant weight in each treatment. b Relationship between stem and total plant weight in each treatment. c Relationship between root and total plant weight in each treatment. d Relationship between aboveground and belowground plant weight in each treatment

plants of control and SA allocated more biomass to stem $(p<0.0001)$ and leaf tissue $(p<0.0001)$ respect to total biomass, and lower proportion to root biomass $(p<0.0001)$ compared to SB plants. These changes in biomass partitioning were reflected in the relationships between biomass of each organ and total biomass, as well as in the aboveground:belowground ratio.

GR did not have a significant effect on the biomass allocation to the different aboveground organs of the plants (leaves, branches, stem). However, belowground biomass was higher for LG than HG families $(p=0.0028)$, resulting in a higher relative allocation to this compartment as well as in a lower above:belowground ratio in LG than HG families (Fig. 3). In all cases, GR effects on biomass allocation were detected as differences in the intercepts, but not in the slopes, of the linear models (Fig. 3). Relative allocation to the stem was higher in HG1 family than in the other three families $(p<0.0001)$. On the other hand, relative allocation to leaves was higher in HG2 compared to the other three families $(p<0.0001)$.

\section{Water relations and hydraulic parameters}

Water stress significantly affected the maximum (pre-dawn) $(p<0.0001)$ and minimum (afternoon) $(p<0.0001)$ daily water potential, with no significant difference between 

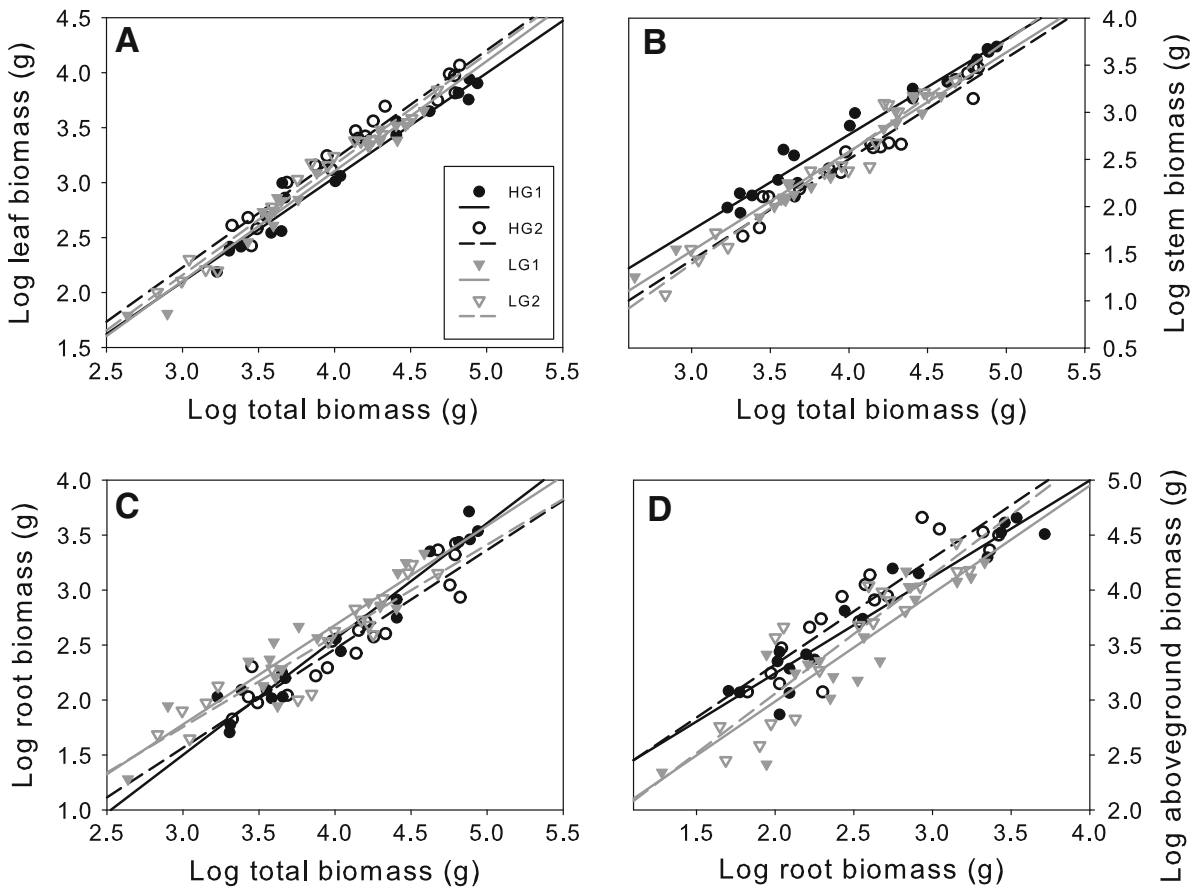

Fig. 3 Allometric relationships for seedlings of four families of Pinus taeda L. differing in mean growth rate. a Relationship between leaf and total plant weight in each family. b Relationship between stem and total plant weight in each family. c Relationship between root and total plant weight in each family. d Relationship between aboveground and belowground plant weight in each family

families considering the whole experiment period $(p=0.848$ and $p=0.467$ for pre-dawn and afternoon values, respectively). The mean (SD) minimum values were $-1.37 \pm 0.25$, $-1.94 \pm 0.58$, and $-2.38 \pm 0.81 \mathrm{MPa}$ in control, SA and SB, respectively. The absolute minimum water potential reached in the different treatments was $-1.5,-2.5$ and $-3.0 \mathrm{MPa}$ for the control, SA and SB, respectively.

The $k_{\mathrm{s}}$ of the branches measured in situ (at midday) was similar between WS treatments and families (only control and more severe stress (SB) level were compared) (Table 2). The average values of $k_{\mathrm{s}}$ measured in November were $0.20 \pm 0.19$ and $0.27 \pm 0.28 \mathrm{~kg} \mathrm{~s}^{-1}$ $\mathrm{m}^{-2} \mathrm{MPa}^{-1}$ for control and SB plants, respectively, while in December the average values were $0.32 \pm 0.36$ and $0.24 \pm 0.14 \mathrm{~kg} \mathrm{~s}^{-1} \mathrm{~m}^{-2} \mathrm{MPa}^{-1}$ for the same treatments. Some plants presented $k_{\mathrm{s}}$ values close to zero in the water stress treatment as well as in the control.

Maximum $k_{\mathrm{s}}$ also showed similar values ( $p>0.05$ in all cases) between GR, WS and family ( $0.57 \pm 0.19$ and $0.58 \pm 0.12 \mathrm{~kg} \mathrm{~s}^{-1} \mathrm{~m}^{-2} \mathrm{MPa}^{-1}$ in control and stress respected). However, WS significantly affected $k_{1}$, which was higher in the water stress treatment than in the control $\left(0.07 \pm 0.027\right.$ and $0.10 \pm 0.038 \mathrm{~kg} \mathrm{~s}^{-1} \mathrm{~m}^{-1} \mathrm{MPa}^{-1}$ in control and SB, respectively; $p=0.010$ ), which can be explained by the lower leaf area of branches in the water deficit treatment. In particular, family LG2 showed a significantly higher $k_{l}$ in SB compared to the control (Table 2).

Comparing in situ $k_{\mathrm{s}}$ values with the maximum $k_{\mathrm{s}}$ values of each family and treatment, it appears that plants of all families lose branch hydraulic conductivity during the hours of 
Table 2 Mean $( \pm \mathrm{SD})$ of maximum leaf specific hydraulic conductivity $\left(k_{1}\right.$ max $)$; maximum specific hydraulic conductivity ( $k_{\mathrm{s}} \max$ ); minimum (in situ) specific hydraulic conductivity measured in November ( $k_{\mathrm{s}}$, min November); minimum (in situ) specific hydraulic conductivity measured in December $\left(k_{\mathrm{s}}\right.$, min December), and ratio between in situ and maximum $k_{\mathrm{s}}$ (November and December average $k_{\mathrm{s}}$ divided by the mean maximum $k_{\mathrm{s}}$ of each family)

\begin{tabular}{lllllll}
\hline Treatment & Family & $k_{1} \max$ & $k_{\mathrm{s}} \max$ & $k_{\mathrm{s}} \min$ & $k_{\mathrm{s}} \min$ & $k_{\mathrm{s}} \min / k_{\mathrm{s}} \max$ \\
\hline Control & $\mathrm{HG} 1$ & $0.09 \pm 0.02$ & $0.53 \pm 0.12$ & $0.34 \pm 0.22$ & $0.60 \pm 0.64$ & 0.89 \\
& $\mathrm{HG} 2$ & $0.06 \pm 0.01$ & $0.44 \pm 0.11$ & $0.10 \pm 0.12$ & $0.19 \pm 0.13$ & 0.33 \\
& $\mathrm{LG} 1$ & $0.07 \pm 0.04$ & $0.69 \pm 0.28$ & $0.24 \pm 0.19$ & $0.18 \pm 0.17$ & 0.30 \\
& LG2 & $0.06 \pm 0.02$ & $0.61 \pm 0.17$ & $0.13 \pm 0.21$ & $0.32 \pm 0.21$ & 0.37 \\
Stress B & HG1 & $0.11 \pm 0.04$ & $0.57 \pm 0.08$ & $0.38 \pm 0.22$ & $0.33 \pm 0.10$ & 0.62 \\
& HG2 & $0.10 \pm 0.06$ & $0.60 \pm 0.14$ & $0.34 \pm 0.21$ & $0.22 \pm 0.13$ & 0.47 \\
& LG1 & $0.07 \pm 0.02$ & $0.48 \pm 0.05$ & $0.14 \pm 0.20$ & $0.21 \pm 0.18$ & 0.36 \\
$P_{\mathrm{GR}}$ & LG2 & $0.12 \pm 0.02$ & $0.64 \pm 0.16$ & $0.20 \pm 0.18$ & $0.20 \pm 0.16$ & 0.31 \\
$P_{\mathrm{WS}}$ & & 0.512 & 0.171 & 0.195 & 0.275 & \\
$P_{\mathrm{F} \text { (nested in GR) }}$ & & 0.010 & 0.858 & 0.467 & 0.403 & \\
$P_{\mathrm{GR} \times \text { ws }}$ & & 0.280 & 0.856 & 0.531 & 0.159 & \\
\hline$K_{\mathrm{S}}$ & & 0.133 & 0.356 & 0.715 & \\
\hline
\end{tabular}

$K_{\mathrm{s}}$ values are expressed in $\mathrm{kg} \mathrm{s}^{-1} \mathrm{~m}^{-2} \mathrm{MPa}^{-1}$, and $k_{1}$ values in $\mathrm{kg} \mathrm{s}^{-1} \mathrm{~m}^{-1} \mathrm{MPa}^{-1}$. Probability values of ANOVA are provided for effects of GR: growth rate factor $(\mathrm{HG}=$ high-growth families; $\mathrm{LG}=$ low growth families); WS: water stress factor (control conditions; $\mathrm{SB}=$ severe water stress level); F: family factor nested within GR

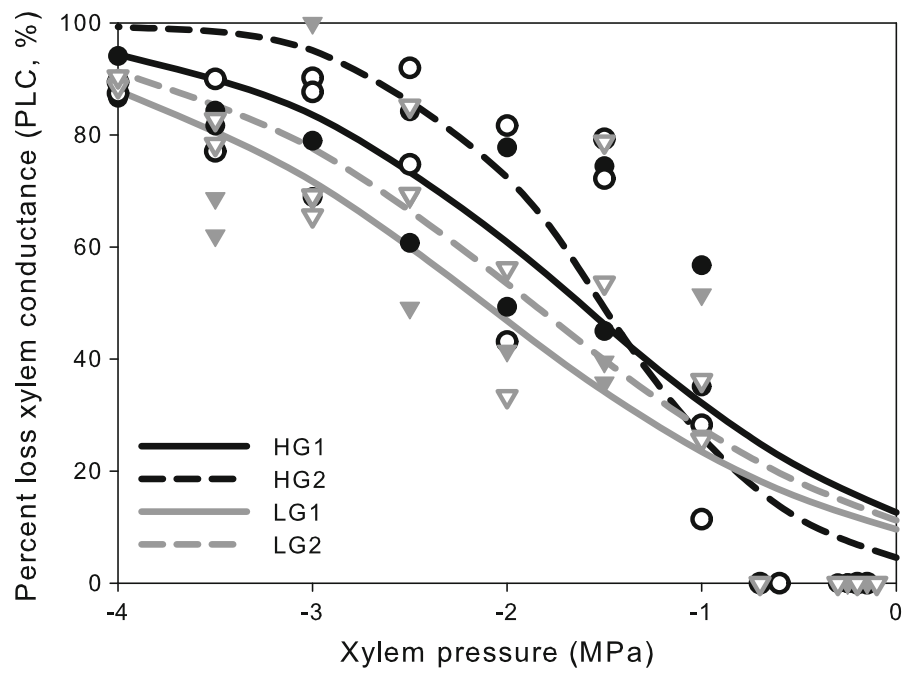

Fig. 4 Percent loss of hydraulic conductivity (PLC) of branch xylem versus the applied air pressure determined in seedlings of four families of Pinus taeda L. HG1 (closed circle) and HG2 (open circle) family: high growth rate families. LG1 (closed triangle) and LG2 (open triangle) family: low growth rate families. Different letters indicate significant differences in whole models between families (F test, $p<0.05)$ 
highest evaporative demand, with no differences between the control and water stressed plants. The HG1 family showed lower $k_{\mathrm{s}}$ losses (lower than $40 \%$ of $k_{\mathrm{s}}$ loss) than all other families, which had a mean $k_{\mathrm{s}}$ loss between 55 and $70 \%$.

The relationship between percent loss of $k_{s}$ and xylem water potential (Fig. 4; Table 3) followed the expected sigmoidal pattern, with a lower vulnerability to cavitation observed in the family LG1 compared to all other families (but significant differences were detected between this family and both HG families ( $F$ test, $p<0.05$ ) and not with LG2 family (Table 3). Average $P_{50}$ for all families was $-1.77 \mathrm{MPa}$, suggesting that minimum water potential values observed in some dates in all treatments led to high levels of $k_{s}$ loss in all cases.

\section{Gases exchange and leaf parameters}

Mean $g_{\mathrm{s}}$ did not differ between GR and families, but was affected by WS treatments. During the evaluation period it began to differ statistically between the control and water stress treatments in October, and continued until the end of the experiment, decreasing the mean $g_{\mathrm{s}}$ in each treatment throughout the period, including the control (data not shown). No difference in $g_{\mathrm{s}}$ was observed between SA and SB treatments. The lowest $g_{\mathrm{s}}$ values were observed in December for all treatments, related to high $D$ values recorded on those measurement dates. Mean $D$ values recorded at 9 a.m. were equal to or lower than $2 \mathrm{kPa}$ from September to December, whereas at 2 p.m. they reached a mean maximum of $5.9 \mathrm{kPa}$ in December. LG families were characterized by higher $g_{\mathrm{s}}$-at equal $D$ values - than HG families, maintaining relatively high $g_{\mathrm{s}}$ at $D$ levels as high as $6 \mathrm{kPa}$ (Fig. 5a). Stomatal sensitivity to $D$, quantified by the slope of the regression line between $g_{\mathrm{s}}$ and $\ln (D)$, was similar ( $t$ test, $p>0.05$ ) among HG and LG families (Fig. 5a), but whole models differed between HG and LG due to differences in the intercept (covariate analysis, $p<0.0001$ ). For this reason, the ratio between stomatal sensitivity and reference $g_{\mathrm{s}}$ was 0.56 for both HG families, while families LG1 and LG2 had a lower ratio ( 0.53 and 0.45 respectively).

$A_{\max }$ of the plants measured during a period of active growth was affected by GR $(p<0.0001)$ and WS $(p<0.0001)$ treatment, with a significant effect of family within GR $\left(p=0.006\right.$ ) (Fig. 5b). In both HG families and in LG2 family, $A_{\max }$ in control plants was higher than in both WS treatments, with no differences between them, but in LG1 significant differences were detected between the three WS treatments. LG families had higher $A_{\max }$ than HG families, with mean family values (for all treatments) of $4.6 \pm 3.7$, $4.8 \pm 2.8, \quad 8.3 \pm 2.4$ and $6.4 \pm 3.2 \mu \mathrm{mol} \mathrm{m}^{2} \mathrm{~s}^{-1}$ for HG1, HG2, LG1 and LG2, respectively.

Table 3 Hydraulic safety parameters under optimal water conditions in four families of Pinus taeda L.

\begin{tabular}{lllllll}
\hline Family & Slope & $P_{12}$ & $P_{50}$ & $P_{88}$ & $\mathrm{R}^{2}$ adjusted & F test \\
\hline HG1 & $1.2 \pm 0.22$ & -0.06 & $-1.6 \pm 0.16$ & -3.3 & 0.84 & $\mathrm{ab}$ \\
HG2 & $2.0 \pm 0.45$ & -0.50 & $-1.5 \pm 0.13$ & -2.5 & 0.83 & $\mathrm{a}$ \\
LG1 & $1.0 \pm 0.18$ & -0.10 & $-2.1 \pm 0.17$ & -4.1 & 0.81 & $\mathrm{c}$ \\
LG2 & $1.1 \pm 0.19$ & -0.09 & $-1.9 \pm 0.17$ & -3.7 & 0.82 & $\mathrm{bc}$ \\
\hline
\end{tabular}

Mean \pm SD of parameters derived from vulnerability to cavitations curves. Adjusted $R^{2}$ and results of $F$ test ( $\alpha=0.05$ ) comparing whole models between families. HG1 and HG2: high growth families; LG1 and LG2: low growth families 


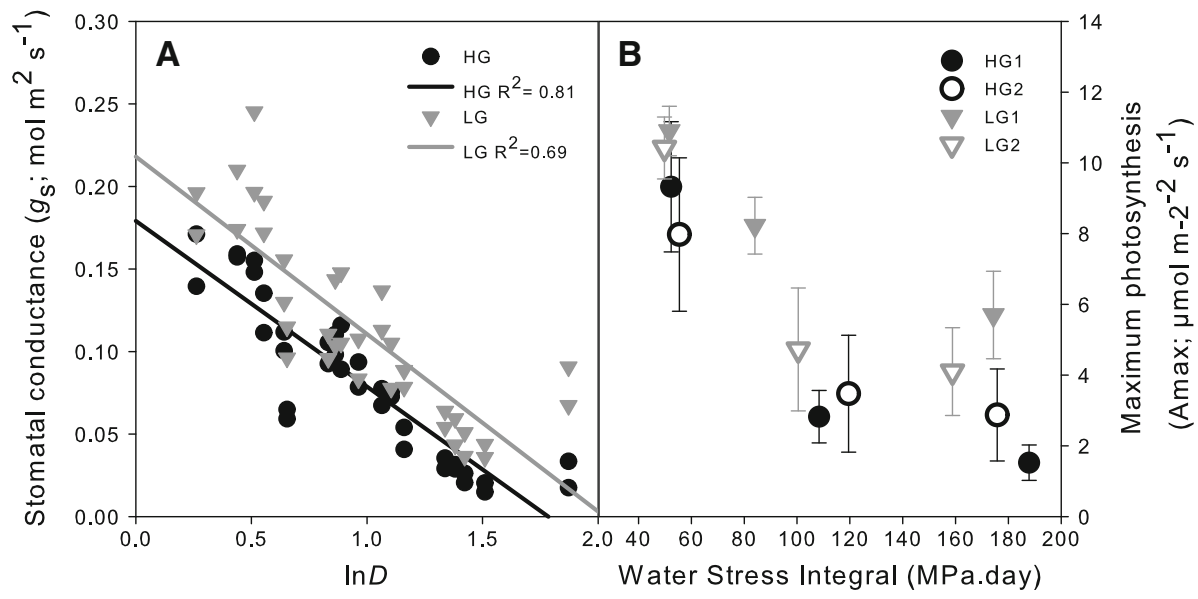

Fig. 5 Stomatal sensitivity to vapor pressure deficit of the atmosphere $(D)$ and maximum photosynthesis measured in high growth (HG) and low growth (LG) families of Pinus taeda L. a Stomatal conductance $\left(g_{\mathrm{s}}\right.$, $\mathrm{mol} \mathrm{m} \mathrm{s}^{-1}$ ) related to the natural logarithm of $D$ in the control treatment. b Maximum photosynthesis $\left(\mu \mathrm{mol} \mathrm{m} \mathrm{s}^{-1}\right)$ measured at light saturation $\left(1200 \mu \mathrm{mol} \mathrm{m} \mathrm{s}^{-1}\right)$. Average values $($ and $\pm \mathrm{SD})$ are presented per family and treatment as a function of the water stress integral (MPa day)

The total chlorophyll $\left(\mathrm{cl}_{\mathrm{t}}\right)$ in leaves was not affected by GR nor WS ( $p=0.458$ and 0.803 , respectively). However, the proportions of chlorophyll a $\left(\mathrm{cl}_{\mathrm{a}}\right)$ and chlorophyll $\mathrm{b}\left(\mathrm{cl}_{\mathrm{b}}\right)$ were affected by WS. In general, control $\left(2.05 \pm 0.96 \mathrm{mg} \mathrm{g}^{-1}\right)$ and SA treatment $\left(2.23 \pm 1.1 \mathrm{mg} \mathrm{g}^{-1}\right)$ plants had higher $\mathrm{cl}_{\mathrm{a}}$ concentration than $\mathrm{SB}$ treatment plants $\left(1.15 \pm 0.7 \mathrm{mg} \mathrm{g}^{-1}\right)$. In contrast, plants subject to $\mathrm{SB}$ had higher $\mathrm{cl}_{\mathrm{b}}$ concentrations $\left(2.35 \pm 1.23 \mathrm{mg} \mathrm{g}^{-1}\right)$ than control $\left(1.45 \pm 1.15 \mathrm{mg} \mathrm{g}^{-1}\right)$ and SA $\left(1.5 \pm 0.64 \mathrm{mg} \mathrm{g}^{-1}\right)$ treatments.

Leaf nitrogen concentration $\left(N_{\mathrm{f}}\right)$ was affected by GR $(p=0.027)$ and WS $(p<0.0001)$. Water stress significantly increased $N_{\mathrm{f}}(1.43 \pm 0.15$ and $1.41 \pm 0.20 \%$ for SA and SB, respectively) compared to control plants $(1.18 \pm 0.13 \%)$, and $\mathrm{LG}$ families presented higher $N_{\mathrm{f}}$ than HG families. The integration of $N_{\mathrm{f}}$ in the whole foliar biomass showed that there was a trade-off between variables, resulting in similar values of nitrogen in the crown $\left(N_{\mathrm{c}}\right)$ in all families $(p=0.147)$. The WS treatment had a significant effect on $N_{\mathrm{c}}$, showing average values of $0.45 \pm 0.11,0.35 \pm 0.08$ and $0.18 \pm 0.05 \mathrm{~g} N$ per plant for control, SA and SB treatments, respectively $(p<0.0001)$.

\section{Resources use efficiency}

Plant growth efficiency (GE) was affected by WS ( $p<0.0001)$, and family nested in GR $(p<0.0001)$. GE showed an exponential drop in water stressed plants compared to control plants, with no significant difference between SA and SB. Mean GE values (for all the families) were $2.79 \pm 0.61,1.28 \pm 0.38$ and $1.27 \pm 0.50 \mathrm{~cm}^{3} \mathrm{~g}^{-1}$ for control, SA and SB, respectively.

At family level, HG2 had the lowest GE, differing significantly from the HG1 family $(p<0.0001)$; moreover, the GE of the HG1 family was markedly greater than the others (Fig. 6a). The GE did not differ between the LG families $(p=0.934)$, whose values were between those of HG1 and HG2. 


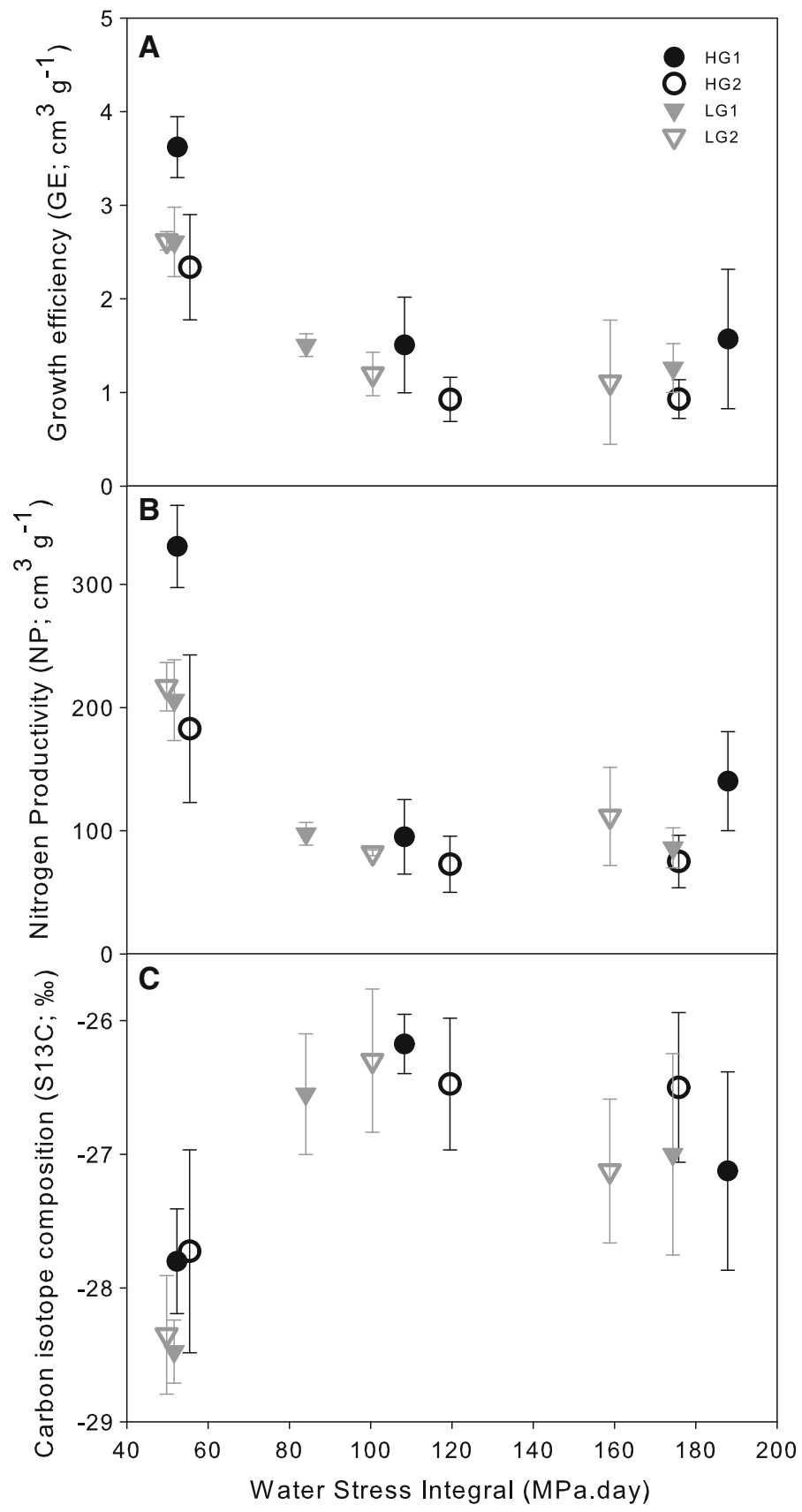

Fig. 6 Variables used as proxy of resources use efficiency measured in high growth (HG) and low growth (LG) families of Pinus taeda L. as a function of the water stress integral (MPa day), mean values \pm SD. a Growth efficiency $(\mathrm{GE})=$ stem volume increment per unit of leaf biomass $\left(\mathrm{cm}^{3} \mathrm{~g}^{-1}\right)$. b Nitrogen productivity $(\mathrm{NP})=$ absolute stem volume increment per gram of leaf nitrogen $\left(\mathrm{cm}^{3} \mathrm{~g}^{-1}\right)$. c Carbon isotope composition in woody tissue (stem + branches, $\delta^{13} \mathrm{C}, \%$ ) 
Nitrogen productivity (NP) was affected by WS treatment $(p<0.0001)$ and family $(p<0.0001$ ), with similar behavior to the GE (exponential decay at water stress conditions) (Fig. 6b). No difference was observed in NP between SA and SB $(p>0.05)$. The HG1 family had higher NP than HG2 family $(p<0.0001)$, regardless of the treatment applied (Fig. 6b). No differences were found between LG families $(p=>0.05)$.

In contrast, both water stress treatments showed a significant reduction in the discrimination against ${ }^{13} \mathrm{C}$ isotope compared to the control (Fig. $\left.6 \mathrm{c}\right)(p<0.0001)$, suggesting a greater $\mathrm{WUE}_{\mathrm{i}}$. Moreover, significant differences were observed between SA and SB, with the highest ${ }^{13} \mathrm{C}$ proportion in SA (highest $\mathrm{WUE}_{\mathrm{i}}$ ). In addition, a GR effect was detected on ${ }^{13} \mathrm{C}$ discrimination $(p=0.039)$, with no family effect $(p=0.776)$. In this regard, HG families presented higher (less negative) $\delta^{13} \mathrm{C}$ than LG families, suggesting a stronger stomatal control of transpiration in the former species.

\section{Correlation between growth and morpho-physiological variables}

There were high positive correlations $(r>0.75)$ between the absolute stem volume increment during the study period and final biomass of the different plant components (Table 4). However, contrary to initial expectations, negative correlations were observed between the absolute stem increment and wood $\left(k_{1}, r=-0.38\right)$ or leaf $\left(A_{\max }: r=-0.57\right)$ physiological variables, with no significant correlation with branch $k_{\mathrm{s}}(p=0.3)$ and $\mathrm{cl}_{\mathrm{t}}$ $(p=0.2)$. This means that the fastest-growing plants during the experiment had the lowest water conductive and carbon fixation capacities, both expressed per unit of leaf area.

Table 4 Pearson correlation coefficient between absolute stem volume increment $\left(\mathrm{VI}_{\mathrm{abs}}\right)$ or relative stem volume increment $\left(\mathrm{VI}_{\mathrm{rel}}\right)$ during the experiment (September 2011-January 2012) and different physiological and morphological traits

\begin{tabular}{|c|c|c|c|c|}
\hline \multirow[t]{2}{*}{ Parameter } & \multicolumn{2}{|l|}{$\mathrm{VI}_{\text {abs }}$} & \multicolumn{2}{|l|}{$\mathrm{VI}_{\text {rel }}$} \\
\hline & $r$ & $p$ & $r$ & $p$ \\
\hline$k_{\mathrm{s}}$ & 0.19 & 0.3000 & 0.33 & 0.07 \\
\hline$k_{1}$ & -0.38 & 0.0300 & -0.31 & 0.08 \\
\hline$A_{\max }$ & -0.57 & 0.020 & 0.26 & 0.330 \\
\hline$N_{\mathbf{c}}$ & 0.69 & 0.0003 & -0.450 & 0.080 \\
\hline $\mathrm{cl}_{\mathrm{t}}$ & -0.24 & 0.1678 & 0.22 & 0.196 \\
\hline $\mathrm{cl}_{\mathrm{a}}$ & -0.13 & 0.4635 & 0.02 & 0.920 \\
\hline $\mathrm{cl}_{\mathrm{b}}$ & -0.26 & 0.1279 & 0.20 & 0.252 \\
\hline Whole plant biomass & 0.91 & $<\mathbf{0 . 0 0 0 1}$ & -0.530 & 0.010 \\
\hline Aboveground biomass & 0.87 & $<0.0001$ & -0.490 & 0.020 \\
\hline Belowground biomass & 0.80 & $<\mathbf{0 . 0 0 0 1}$ & -0.510 & 0.010 \\
\hline Stem biomass & 0.96 & $<0.0001$ & -0.480 & 0.010 \\
\hline Branch biomass & 0.69 & $<0.0001$ & -0.470 & 0.020 \\
\hline Leaf biomass & 0.75 & $<0.0001$ & -0.430 & 0.030 \\
\hline
\end{tabular}

Bold type highlights $p$ values significant at the 0.05 level. $k_{\mathrm{s}}=$ specific hydraulic conductivity of branch wood; $k_{1}=$ leaf specific hydraulic conductivity ( $k_{\mathrm{s}} /$ leaf biomass); $A_{\max }=$ maximum net photosynthesis at light saturation $\left(\mu \mathrm{mol} . \mathrm{m}^{2} \mathrm{~s}^{-1}\right) ; N_{\mathrm{C}}=$ nitrogen in the crown $(g) ; \mathrm{Cl}_{\mathrm{t}}$ : total chlorophyll content $\left(\mathrm{mg} \mathrm{g}^{-1}\right)$; $\mathrm{Cl}_{\mathrm{a}}=$ chlorophyll a content $\left(\mathrm{mg} \mathrm{g}^{-1}\right) ; \mathrm{Cl}_{\mathrm{b}}=$ chlorophyll b content $\left(\mathrm{mg} \mathrm{g}^{-1}\right)$ 
No significant correlation was found between the relative stem volume increment and the functional parameters analyzed $\left(\mathrm{Cl}_{\mathrm{t}}, A_{\max }, k_{1}\right)$, but a marginally significant $(p=0.07)$ positive correlation was detected between relative stem increment and branch $k_{\mathrm{s}}$. In addition, contrary to that observed in the absolute values of stem volume increment, the relative values showed negative correlations with descriptive biomass variables and biomass allocation within the plant ( $r$ between -0.43 and -0.53 ), where the largest plants had the lowest increase relative to the involved organ size (Table 4).

\section{Discussion}

\section{Ecophysiological processes explaining differential growth in HG and LG families}

This study involved two families considered as having high growth rates (HG) and two families with low growth rates (LG). These trends were confirmed in the initial plant size prior to water stress treatments application (at 8 months of age), and at the end in the control treatment, the HG families having greater biomass and stem volume than the LG families. It is important to consider, however, that in spite of HG families presenting higher absolute growth during the study period, LG families presented significantly higher relative growth.

Correlations analyses relating stem growth and the studied morpho-physiological variables indicated that morphological traits such as total biomass and biomass in the different aboveground compartments were those that best correlated with the stem volume increment during the study period. Since larger plants at the end of the experiment were also those with higher initial size, it appears that the initial higher size of HG plants was the main factor explaining higher absolute growth in those plants compared to LG individuals. Some studies mention that the absolute growth is more effective than the relative growth to explain the differences in growth observed in different $P$. taeda genotypes (Apinwall et al. 2013) and in other genera of Pinaceae (Van den Driessche 1992), in agreement with our results. It is important to determine, therefore, which processes are responsible for initial differences in plant size, processes that operate at very initial stages of seedling development. These processes apparently changed in posterior stages, such as the evaluated here, since relative growth rate was higher in LG than in HG families.

On the other hand, HG families were different from LG families in their photosynthetic capacity $\left(A_{\max }, N_{\mathrm{f}}\right)$, maximum $g_{\mathrm{s}},{ }^{13} \mathrm{C}$ discrimination and stomatal sensitivity to $D$ (relative to the maximum $g_{\mathrm{s}}$ ). In those traits, both $\mathrm{HG}$ families presented similar patterns between them, characterized by lower $A_{\max }$, lower $N_{\mathrm{f}}$, lower maximum $g_{\mathrm{s}}$, and higher relative stomatal sensitivity to $D$, than LG families. All these traits could be useful to explain, at least in part, the higher relative growth observed in LG compared to HG families, since they can lead to a higher $C$ fixation per unit of leaf biomass or area.

However, in both HG families, biomass allocation and in vivo levels of $k_{\mathrm{s}}$ losses presented opposite trends between them, making impossible to relate a unique combination of traits to their final growth patterns. The HG2 family presented the highest allocation to the leaf compartment of all studied families, coinciding with antecedents reporting a positive correlation between leaf biomass and whole plant biomass productivity in $P$. taeda (Teskey et al. 1987). On the other hand, the strategy of the HG1 family was characterized by a greater investment in stem per unit of leaf area, decreasing the Huber value with 
respect to all other families. While individual $k_{1}$ branches did not differ from that determined in the other families, at the whole plant level, this type of aboveground partitioning would increase the total leaf hydraulic conductance and capacitance (water storage), contributing to an efficient water transport, consistent with high growth rates (Tyree and Ewers 1991).

As a consequence of differences in biomass partitioning between both HG families, the HG1 family was characterized by high GE and NP, while the HG2 family was the least efficient in these terms. LG families presented efficiency values close to those of the HG2 family. Our results agree with those of Apinwall et al. (2013), who found no relationship between productivity and growth efficiency for $P$. taeda, where the most productive genotypes were not necessarily the most efficient. Another precedent for P. taeda (Birk and Vitousek 1986) showed that individual plants with higher NUE did not necessarily have higher total biomass.

Finally, contrary to many studies reporting a close relationship between growth and maximum hydraulic conductivity of different plant organs (e.g. Domec and Gartner 2003; Wang et al. 2003; Brodribb et al. 2005; Kondoh et al. 2006), in this study, we did not find any correlation between maximum hydraulic capacity $\left(k_{\mathrm{s}}, k_{\mathrm{l}}\right)$ of branches and growth. However, under control conditions, one of the high growth families (HG1) was outstanding by their lower levels of $k_{\mathrm{s}}$ losses compared to all the other studied families. Vulnerability to cavitation of branch xylem was not particularly lower in this famility, therefore it appears that a higher hydraulic conductance and/or capacitance reducing xylem tension could contribute to high growth under the high evaporative demand conditions of the study region in this family. Nevertheless, the fact that the other HG family did not present the same strategy suggests that it is not the unique strategy to explain high absolute growth.

On the other hand, both studied LG families presented similar strategies between them in most of the studied variables. They were characterized by a high capacity for carbon exchange per unit leaf area, and a higher biomass allocation to roots compared to $\mathrm{HG}$ families. This increased allocation to roots may be responsible for their lower initial size (which was measured in aereal compartments), counterbalancing their high intrinsic growth capacity which was only reflected in relative terms.

\section{Responses of HG and LG families to drought stress: Is there a trade-off?}

In contrast to control conditions, there were no differences in growth between HG and LG families under moderate or high soil water deficit. Bongarten and Teskey (1987) also observed similar behavior of significant differences in growth under high water availability and no difference under dry conditions when they compared coastal and continental provenances of P. taeda. However, other studies in this species (Aspinwall et al. 2011b; Cannell et al. 1978) show genetic differences along the whole range of site productivities.

Studies reporting biomass allocation patterns in $P$. taeda indicate that in response to a water stress event there is an increase in allocation to the stem (Gebremedhin 2003) at the expense of a decrease in root biomass, without foliar biomass modifications (Green et al. 1994). In the present study, we did not find a unique allocation response to drought by the studied families. Allocation to roots in response to drought decreased or did not vary in HG families, as previously reported for the species, but it increased under the severe drought treatment in both LG families, strategy in agreement with the optimal partitioning theory (Bloom et al. 1985).

Minimum daily leaf water potential differed among WS treatments, reflecting an anisohydric behavior (Tardieu and Simonneau 1998), with no clear differences between the studied 
P. taeda families. The species has been previously described as isohydric (Hacke et al. 2000; Ewers et al. 2000) or isohydrodynamic (Gonzalez-Beneque and Martin 2010), which means that the minimum leaf water potential may change (as observed in the present study) but the gradient between pre-dawn and minimum water potential remains the same. In the present study, the observed behavior was due to poor stomatal control of transpiration by the plants, which maintained their stomata partially open even at $D$ as high as $5 \mathrm{kPa}$. Although there was a linear response of $g_{\mathrm{s}}$ to increasing $\ln (D)$, coincident with that reported by Faustino et al. (2013) for field conditions, analyzing the reference $g_{\mathrm{s}}$ (i.e. $g_{\mathrm{s}}$ at $1 \mathrm{kPa}$ ) and the stomatal sensitivity to $D$ (slope of the linear model) of the different GR groups, it is observed that both have a ratio of $<0.6$. Differences in this ratio suggest a more or less isohydric behavior among families, showing a distinct stomatal control of water potential between them (Oren et al. 1999). The LG2 family behavior was the most noteworthy, showing a lower ratio than the other families ( $0.45 \mathrm{vs}$. more than 0.5 in the other three families). Some genotypes of $P$. taeda have been previously described as also insensitive to increasing $D$, presenting high stomatal conductance and also increased susceptibility to cavitation (Tang et al. 2003; Aspinwall et al. 2011a). In this regard, in spite of not find a correlation between maximum $k_{\mathrm{s}}$ and mean growth in the studied families, this does not mean that different cavitation levels-due to differences in stomatal regulation of minimum leaf water potential-has no functional meaning on carbon fixation during water stress periods. In this regard, the higher stomatal sensitivity to $D$ found in some genotypes by Aspinwall et al. (2011a) was related to a maximization of carbon assimilation when weather conditions were favorable and minimization of stress and water loss under unfavorable conditions. Similarly, HG1 family was outstanding by its lower $k_{\mathrm{s}}$ losses and the highest growth under control conditions. It is important to note, however, that we did not find growth differences between families under water stress conditions, thus suggesting that the potential advantage of family HG1 is not enough to allow a better growth performance of this family under soil water deficit compared to the other studied families.

Returning to the main hypothesis of this study, the proposed trade-off between growth or $C$ fixation and water stress resistance in woody species is suggested on the basis of relating the former to plant hydraulic efficiency and the latter to vulnerability to cavitation. From the results of our study, it is not possible to assign a central role of maximum $k_{\mathrm{s}}$ or $k_{1}$ of branches to explain the growth differences between family groups. This makes the hypothesis quite senseless from its basis. So, if we take into account absolute growth within each treatment - and not the relative decrease between maximum and minimum growth of each family-, it appears that there is not a trade-off between growth and resistance to water stress in $P$. taeda, at least at the evaluated age and studied genotypes, but there are combinations of traits, such as those in the HG families in this study, which maximize both processes. This may be because the maximum absolute growth rates of these families are not due to increased $C$ fixation capacity at the leaf level or increased water conduction capacity at the branch level, but to a higher initial plant size-due to increased biomass allocation to aboveground organs - in combination to strategies that enable the maintenance of their physiological capacity under high evaporative demand.

\section{Conclusions}

Differences in growth among HG and LG plants occurred only with high soil water availability, whereas all families had similar growth under soil water restriction. These results suggest that it would be appropriate to use plants with high growth rate (HG 
families) because they would grow more when conditions are favorable, and at the same rate as other slow-growing families under drought conditions. It appears that these highgrowth families have high initial growth rates - at the seedling stage-leading to high plant size, and from any point in time in their development, their relative growth could be similar or even lower than LG families. However, their higher size allows for a higher biomass accumulation in absolute terms compared to LG families. Under field conditions, where the families were evaluated in the Breeding Program and classified as LG and HG families, size differences between families ( $\mathrm{HG}>\mathrm{LG}$ ) are maintained at least at the age of 5 years. Those HG families presented also differential (but no unique) biomass allocation patterns and a relatively high stomatal control of water potential compared to LG families. Although our study did not find a differential advantage of any of the strategies presented by HG1 and HG2 to deal with stressful conditions, it is expected that the HG1 family strategy (high allocation to stem and low $k_{\mathrm{s}}$ losses) would be the most efficient dealing with water deficit conditions and using available environmental resources.

Finally, we found a relatively low stomatal control of water potential resulting in moderate to high $k_{\mathrm{s}}$ losses in all the studied families, even under conditions of high soil water content (but high $D$ ). Likewise, other species selected and cultivated for their high growth rates have a similar strategy, operating at the limit of their functional thresholds (e.g. Eucalyptus globulus, Pita et al. 2005). This strategy allows them to have very high growth under optimal water conditions, have significant growth within certain stress ranges (as evaluated in the present trial), but could be lethal under stress conditions exceeding these thresholds. This must be taken into account considering the use of the species in marginal sites and/or the potential impact of more severe water stress in the framework of climatic change.

Acknowledgments The authors thank Iris Figueredo, Delia Sosa and Otto Knebel for their cooperation in the greenhouse work, and Fidelina Silva for a first translation of the manuscript. We gratefully acknowledge the time and expertise devoted to statistical analyses in R software by Adriana Quiñones Martorello under the generous advice of the statistician Gloria Monterrubbianesi.

\section{Compliance with ethical standards}

Conflict of interest No conflicts of interest are declared.

\section{References}

Apinwall J, King JS, McKeand SE (2013) Productivity differences among loblolly pine genotypes are independent of individual-tree biomass partitioning and growth efficiency. Trees 27:533-545

Aspinwall MJ, King JS, McKeand SE, Domec JC (2011a) Leaf-level gas exchange uniformity and photosynthetic capacity among loblolly pine (Pinus taeda L.) genotypes of constrasting inherent genetic variation. Tree Physiol 31:78-91

Aspinwall MJ, King JS, McKeand SE, Bullock BP (2011b) Genetic effects on stand-level uniformity and above- and belowground dry mass production in juvenile loblolly pine. For Ecol Manag 262:609-619

Baker JB, Langdon OG (2012) Pinus taeda L. Reporte USFS http://www.na.fs.fed.us/pubs/silvics_manual/ Volume_1/pinus/taeda.htm. Accessed 10 Oct 2012

Birk EM, Vitousek PM (1986) Nitrogen availability and nitrogen use efficiency in loblolly pine stands. Ecology 67:69-79

Bloom AJ, Chapin FS, Mooney HA (1985) Resource limitation in plants-an economic analogy. Annu Rev Ecol Evol Syst 16:363-392

Bongarten BC, Teskey RO (1987) Dry weight partitioning and its relationship to productivity in loblolly pine seedlings from seven sources. For Sci 33:255-267 
Bréda N, Huc R, Granier A, Dreyer E (2011) Temperate forest trees and stands under severe drought: a review of ecophysiological responses, adaptation processes and long-term consequences. Ann For Sci 63:625-644

Brodribb TJ, Holdbrook NM, Hill RS (2005) Seedling growth in conifers and angiosperms: impacts of contrasting xylem structure. Aust J Bot 53:749-755

Burgess SS, Pittermann OJ, Dawson TE (2006) Hydraulic efficiency and safety of branch xylem increases with height in Sequoia sempervirens (D. Don) crowns. Plant Cell Environ 29:229-239

Cannell MGR, Bridgwater FE, Greenwood MS (1978) Seedling growth rate, water stress responses and rootshoot relationships related to eight-year volumes among families of Pinus taeda L. Silvae Genet 27:237-248

Domec JC, Gartner BL (2003) Relationship between growth rates and xylem hydraulic characteristics in young, mature and old-growth ponderosa pine trees. Plant Cell Environ 26:471-483

Domec JC, Lachenbruch B, Meizner FC (2006) Bordered pit structure and function determine spatial Patterns of air-seeding thresholds in xylem of Douglas-fir (Pseudotsuga menziesii; Pinaceae) trees. Am J Bot 93:1588-1600

Ewers BE, Oren R, Sperry JS (2000) Influence of nutrient versus water supply on hydraulic architecture and water balance in Pinus taeda. Plant Cell Environ 23:1055-1066

Faustino L, Bulfe N, Pinazo M, Goya J, Martiarena R, Knebel O, Graciano C (2011) Crecimiento inicial de Pinus taeda L. en suelo pedregoso de la provincia de Misiones, en respuesta a la fertilización con P y N. Yvyrareta 18:52-57

Faustino LI, Bulfe NML, Pinazo MA, Monteoliva SE, Graciano C (2013) Dry partitioning and hydraulic traits in Young Pinus taeda trees fertilized with nitrogen and phosphorus in a subtropical area. Tree Physiol 33:241-251

Fernández ME, Gyenge J, Graciano C, Varela S, Dalla Salda G (2010) Conductancia y conductividad hidráulica. In: Fernández ME, Gyenge J (eds) Técnicas de medición en Ecofisiología vegetal. Concepto y procedimientos, Buenos Aires, pp 53-68

Gebremedhin MT (2003) Variation in growth, water relation, gas exchange, and stable carbon isotope composition among clones of lobollly pine (Pinus taeda L.) under water stress. Dissertation, University of Florida

Gonzalez-Beneque CA, Martin TA (2010) Water availability and genetic effect on water relations of loblolly pine (Pinus taeda) stand. Tree Physiol 30:376-392

Green TH, Mitchell RJ, Gjerstad DH (1994) Effect of the nitrogen on the response of loblolly pine to drought. New Phytol 128:145-152

Hacke UG, Sperry JS (2001) Functional and ecological xylem anatomy. Perspect Plant Ecol Evolut Syst 4:97-115

Hacke UG, Sperry JS, Ewers BE, Ellsworth DS, Schäfer KVR, Oren R (2000) Influence of soil porosity on water use in Pinus taeda. Oecologia 124:495-505

Hoefs J, Schidlowski M (1967) Carbon isotope composition of carbonaceous matter from the Precambrian of the Wirwatersrand system. Science 155:1096-1098

Hulme M, Sheard N (1999) Escenarios de Cambio Climático para Argentina. Unidad de Investigación Climática, Norwich

Inskeep WP, Bloom PR (1985) Extinction coefficients of chlorophyll a and b in $N, N$-dimethylformamide and $80 \%$ acetone. Plant Physiol 77:483-485

IPCC (2007) Cambio climático 2007: Informe de síntesis. Contribución de los Grupos de trabajo I, II y III al Cuarto Informe de evaluación del Grupo Intergubernamental de Expertos sobre el Cambio Climático [Equipo de redacción principal: Pachauri RK, Reisinger A (directores de la publicación)]. IPCC, Ginebra, Suiza

Kondoh S, Yahata H, Nakashizuka T, Kondoh M (2006) Interspecific variation in vessel size, growth and drought tolerance of broad-leaved trees in semi-arid regions of Kenya. Tree Physiol 26:899-904

MAGyP (2013) Argentina: Plantaciones forestales y gestión sostenible

Martiarena RA, Frangi JM, Von Wallis A, Arturi MF, Fassola HE, Fernández RA (2014) Propiedades del suelo y sus relaciones con el IS en plantaciones de Pinus taeda L. en la Mesopotamia Argentina. AUGMDOMUS 6:47-65

Myers BJ (1988) Water stress integral-a link between short-term and long-term growth. Tree Physiol 4:315-324

Oren R, Sperry JS, Katul GG, Pataki DE, Ewers BE, Phillips N, Schäfer KVR (1999) Survey and synthesis of intra and interspecific variation in stomatal sensitivity to vapour pressure deficit. Plant Cell Environ 22:1515-1526

Pammenter NW, Vander Willigen C (1998) A mathematical and statistical analysis of the curves illustrating vulnerability of xylem to cavitation. Tree Physiol 18:589-593 
Panarello HO (1987) Relaciones entre isótopos de elementos livianos para estudiar procesos ambientales y paleotemperaturas. PhD thesis, Universidad de Buenos Aires, FCEN, Buenos Aires, Argentina, p 105

Pita P, Cañas I, Soria F, Ruiz F, Toval G (2005) Use of physiological traits in tree breeding for improved yield in drought-prone environments. The case of Eucalyptus globulus. Investig Agrar Sist Recur For 14:383-393

Rice KJ, Matzner SL, Byer W, Brown JR (2004) Patterns of tree dieback in Queensland, Australia: the importance of drought stress and the role of resistance to cavitation. Oecologia 139:190-198

Sperry JS, Pockman WT (1993) Limitation of transpiration by hydraulic conductance and xylem cavitation in Betula occidentalis. Plant Cell Environ 16:279-287

Sperry JS, Meinzer FC, McCulloh KA (2008) Safety and efficiency conflicts in hydraulic architecture: scaling from tissues to trees. Plant Cell Environ 31:1-14

Tang Z, Chambers JL, Sword MA, Barnett JP (2003) Seasonal photosynthesis and water relations of juvenile loblolly pine relative to stand density and canopy position. Trees 17:424-430

Tardieu F, Simonneau T (1998) Variability among species of stomatal control under fluctuating soil water status and evaporative demand: modelling isohydric and anisohydric behaviours. J Exp Bot 49:419-432

Team RC (2014) R: a language and environment for statistical computing. R: Foundation for Statistical Computing, Viena

Teskey RO, Bongarten BC, Cregg BM, Dougherty PM, Hennessey TC (1987) Physiology and genetics of tree growth response to moisture and temperature stress: an examination of the characteristics of loblolly pine (Pinus taeda L.). Tree Physiol 3:41-61

Tyree MT, Ewers FW (1991) Tansley review no 34. The hydraulic architecture of trees and other woody plants. New Phytol 119:345-360

Van den Driessche R (1992) Absolute and relative growth of Douglas-fir seedling of different sizes. Tree Physiol 10:141-152

Wang T, Aitken SN, Kavanagh KL (2003) Selection for improved growth and wood quality in lodgepole pine: effects on phenology, hydraulic architecture and growth of seedlings. Trees 17:269-277

Zar JH (1999) Biostadistical analysis. Prentice Hall press, New Jersey

Zhang JW, Feng Z, Cregg BM, Schumann CM (1997) Carbon isotopic composition, gas exchange, and growth of three populations of ponderosa pine differing in drought tolerance. Tree Physiol 17:461-466 